\title{
Epidemiological and Economical Study on Mycoplasmosis in Goats in Tamil Nadu, India
}

\author{
R. Rishikesavan*, K. M. Palanivel ${ }^{1}$, S. Saravanan ${ }^{2}$, P. Suresh ${ }^{3}$ and S. Sivaseelan ${ }^{4}$
}

Tamil Nadu Veterinary and Animal Sciences University, Department of Veterinary Preventive Medicine, Veterinary College and Research Institute, Namakkal - 637 002, India

*Corresponding author

\begin{tabular}{|l|}
\hline K e y w o r d s \\
Mycoplasmosis, \\
Goats, \\
Seroprevalence, \\
Agroclimatic zone \\
\hline Article Info \\
\hline $\begin{array}{l}\text { Accepted: } \\
\text { 22 December } 2019 \\
\text { Available Online: } \\
\text { 20January } 2020\end{array}$ \\
\hline
\end{tabular}

\section{Keywords}

Mycoplasmosis

Goats,

Seroprevalence,

Accepted:

22 December 2019

20January 2020

A B S T R A C T

The study was carried out to assess the status of Mycoplasmosis in goats by serology, of Mycoplasma spp. from suspected and apparently normal goats and to assess the epidemiological risk factors associated with Mycoplasmosis and economic impact of Mycoplasmosis in organised and unorganised goat farms present in North West Agroclimatic zone of Tamil nadu. Seroprevalence of Mycoplasmosis was assessed by employing slide agglutination test and iELISA. A total of 336 serum samples were collected from organised (122) and unorganised (244) goat farms. High seropositivity was observed in more than 2 years of age group, adult females, particularly breed of Salem black. Animals in intensive system of rearing and located in urban areas shown higher seropositivity. High incidence of Mycoplasmosis was observed in higher in summer months and thatched roofing system. Clinical signs exhibited by the affected goats in the present study were nasal discharge, respiratory distress, arthritis, mastitis, and pneumonia. Economic loss due to Mycoplasmosis was

\section{Introduction}

Mycoplasmosis in goats is a chronic and unnoticed respiratory infection which cost huge economic loss and higher mortality throughout the world especially in temperate regions. The epidemiological factors involved in the disease dynamic of mycoplasmosis are yet to be discovered in epidemiological and diagnostic approaches. Contagious Caprine Plueropnuemoniae is a serious disease of goats, caused by Mycoplasma capricolum subspecies capripneumoniae (Mccp). The disease is characterized by severe serofibrinous pleuropneumonia, very high morbidity $(\sim 100 \%)$, and mortality (80$100 \%$ ). CCPP affects goats in more than 40 countries of the world thereby posing a 
serious threat to goat farming around the globe. The majority of the goats in Tamil nadu are produced on small farms which are distributed almost evenly across the State. It contributes to about 47.3 million rupees to the national economy through various products and by products (Rekib and Vihan, 1997). Of the many diseases, the goat population is mainly susceptible to many respiratory diseases especially in cold winter and poor husbandry practices are the important predisposing factors (Tariq, 1980). Among them, Mycoplasmal infections result in significant losses with a morbidity and mortality may reach 100 per cent (DaMassa et al., 1983).

\section{Materials and Methods}

A total of 336 serum samples, were randomly collected in from organized (122) and unorganized (244) goat farms in various district of North Western Agro climatic Zone of Tamil Nadu. The blood samples were the samples were subjected to Indirect Enzyme Linked Immunosorbent Assay (iELISA) to determine the prevalence of Mycoplasma infection. The seropositivity of Mycoplasma with various risk factors like age, sex, breed, type of rearing, location, season and roof pattern were statistically analyzed by applying Chi - square test.

The ex post losses (direct loss and treatment cost) of the disease at the regional level were assessed using a partial budget model adapted from a spreadsheet suggested by Singh and Prasad (2010).Cost incurred towards treatment, medicine, feed, labour and cost of animals were collected from farmers as real time data to ensure high accuracy.

In general, Mycoplasma infection in goats is sub-acute in nature which reflects the reduced body weight of the animal that causes economic loss to the goat farms. The body weight loss is 2,5 , and 10 per cent for age groups at birth, pre weaning and post weaning respectively and also 10 per cent for adult age group. The information collected on the cost of animal, treatment cost of animal during ailing at respiratory distress and animal selling cost of live weight basis at the study area and major livestock market at different districts at North Western zone of Tamil Nadu.

\section{Results and Discussion}

Different age groups were classified as less than six months, 6 months to one year, one to two years and more than two years. Samples were collected from different breeds like Salem black, Kanni, Tellicherry, Boer cross and non-descript. Goats rearing in intensive and semi intensive, maintaining in rural and urban, roofing by using thatches, tiles and sheets were grouped. Seropositivity is assessed in different season viz., winter, summer, advanced monsoon and retreating monsoon. The percentage of seropositivity in different risk factors is given in table $1 \& 2$.

In this study age group of more than two years, and female goats were shown higher seropositivity, particularly breed of Salem black shown higher seropositivity. This is in correlation with the findings of Teshale (2012) who reported high seropositivity of Mycoplasmosis in female animals and age group of more than two years by employing CFT in Ethiopia and by using ELISA in goats of Jordan (Al-Momani et al., (2008) and by SAT and ELISA in Kashmir (Muheet et.al.2019). The findings in the present study are well correlated with number of samples collected was higher in adult, female and particularly breed of Salem black. There is No similar work related to determinants of diseases had done in Tamil nadu. The high seropositivity was observed in semi-intensive system of rearing, farms located in urban area, during summer season and thatched roofing system. 
Table.1 Determinants of Mycoplasma antibody status Tamil Nadu

\begin{tabular}{|l|c|c|c|}
\hline \multicolumn{1}{|c|}{ Determinants } & $\begin{array}{c}\text { No. of Samples } \\
\text { screened }\end{array}$ & $\begin{array}{c}\text { No. of Sample } \\
\text { Positive }\end{array}$ & Percent Positive \\
\hline Age & \multicolumn{2}{|c|}{} \\
\hline < 6 months & 28 & 02 & 7.14 \\
\hline 6m-1 Yr - & 68 & 13 & 19.11 \\
\hline $\mathbf{1 Y r}-\mathbf{2}$ Yrs & 108 & 29 & 26.85 \\
\hline >2 Yrs & 166 & 59 & 35.54 \\
\hline Sex & & & 19.54 \\
\hline Male & 87 & 17 & 30.38 \\
\hline Female & 283 & 86 & \\
\hline Breed & & & 25.00 \\
\hline Tellicherry & 100 & 25 & 27.27 \\
\hline Salem black & 121 & 33 & 25.00 \\
\hline Boer cross & 32 & 11 & 12.50 \\
\hline Kanni & 08 & 08 & 26.19 \\
\hline Cross Breed & 42 & 11 & 28.86 \\
\hline Non Descript & 67 & 18 & \\
\hline
\end{tabular}

Table.2 Epidemiological risk factors for seroprevalence of Mycoplasmosis in Tamil Nadu

\begin{tabular}{|l|c|c|c|}
\hline \multicolumn{1}{|c|}{ Determinants } & $\begin{array}{c}\text { No. of Samples } \\
\text { screened }\end{array}$ & $\begin{array}{c}\text { No. of Sample } \\
\text { Positive }\end{array}$ & Percent Positive \\
\hline Type of rearing & 69 & 15 & 26.08 \\
\hline Intensive & 196 & 57 & 29.08 \\
\hline Semi intensive & 105 & 25 & 23.80 \\
\hline Free range & & & 26.70 \\
\hline location & 161 & 43 & 25.83 \\
\hline Rural & 209 & 54 & 22.10 \\
\hline Urban & & & 31.06 \\
\hline Season & 95 & 21 & 21.42 \\
\hline Winter & 132 & 41 & 25.21 \\
\hline Summer & 28 & 06 & \\
\hline Advancing monsoon & 115 & 29 & 27.36 \\
\hline Retreating monsoon & & & 30.50 \\
\hline Roof pattern & 190 & 52 & 25.80 \\
\hline Sheet & 118 & 36 & \\
\hline Thatch & 62 & 16 & \\
\hline Tiles & & & \\
\hline
\end{tabular}


Table.3 Econometrics to estimate the loss due to Mycoplasma infections in goat farms

\begin{tabular}{|r|l|r|}
\hline S.No. & \multicolumn{1}{|c|}{ Cost of animals } & $\begin{array}{r}\text { Amount (Rs) } \\
\text { (Book value) }\end{array}$ \\
\hline $\mathbf{1 .}$ & Age & 1800 \\
\hline & Kids & 6000 \\
\hline & Adult & $2.5 \mathrm{Kg}$ \\
\hline $\mathbf{2 .}$ & Production parameter & $6.0 \mathrm{Kg}$ \\
\hline & Birth weight & $12.0 \mathrm{Kg}$ \\
\hline & Body weight at weaning & $20.00 \mathrm{Kg}$ \\
\hline & Body weight at post weaning & \\
\hline $\mathbf{3 .}$ & Body weight at one year & Rs.300/ goat \\
\hline & Rest of treatment & Rs.300/ goat \\
\hline & Mastitis & Rs.330/goat \\
\hline & Arthritis & Rs.120/ goat \\
\hline $\mathbf{4 .}$ & Cost of production loss & \\
\hline & $\begin{array}{l}\text { Loss due to reduced body weight } \\
\text { /Kg/animal }\end{array}$ & \\
\hline $\mathbf{5 .}$ & Incidence rate (\%) & 28.6 \\
\hline & Morbidity \\
\hline & Mortality & 28.5 \\
\hline
\end{tabular}

The reason in high seropositivity in summer months might be due to picking up of the infection in rainy season and seroconversion during summer, which is contraindicated with Muheet, et al., (2019) CCPP infection is found to be higher seropositivity in adult female animals during winter season.

The high seropositivity was observed in semi intensive system of rearing which is contraindicated with the findings of Teshale (2012) who reported high infection in intensive system of rearing where the animals gathered together for watering and feeding will enhance the possibility of precipitation Mycoplasma. Similar findings were also reported by Singh et al., (1999) who reported high seropositivity in organised goat farms rather than in free ranging flocks.

Total economic loss due to reduction body weight, treatment cost and mortality in is
Rs.10259.40, Rs.48300.00 and Rs.201200.00 respectively. The econometric to assess economic loss is given in table 3 . No reports of economic loss occurred due to Mycoplasma infection in goats in India. However, economic loss due to respiratory infections of goats (Mycoplasmosis) has been calculated by Singh and Prasad (2008) who stated that total annual average loss due to all diseases is Rs.264.8 Lakh. Among which loss due to CCPP is 6.4 per cent. The losses due to diseases in goats scaled at national level were estimated at Rs. 11,720 million per annum (Kumar et al., 2003).

\section{References}

Al-Momani, W., M. A. Halablab, M. N. AboShehada, K. Miles, L. Mcauliffe and R. A. J. Nicholas, 2006. Isolation and molecular identification of small ruminant mycoplasmas in Jordan. Small 
Rumin. Res., 65:106-112

Damassa, A. J., D. L. Brooks and H. E. Adler, 1983. Caprine mycoplasmosis: widespread infection in goats with Mycoplasma mycoides ssp. mycoides (Large colony type). Am. J. Vet. Res., 44: 322-325

Kumar V., R. Rama, S. Mehra and P. K. Rout. 2013 Isolation and characterization of Mycoplasma mycoides subspecies capri from milk of natural goat mastitis cases. ISRN Vet Sci ., Article ID: 593029.

Muheet, M., U. M. Hamid, R.P. Oveas, B.Riyaz and M.Yatoo, 2019. Seasonal and periodic rhythmicity of respiratory infections in small ruminants. Biol. RhythmRes., 1-9.

Rekib, A. and V.S. Vihan, 1997. Economic losses in goat production diseases. Proceedings of III National Seminar on Small Ruminant Diseases. CIRG, Mukhdoom, Mathura.P:1-9

Singh, R.K, N.C. Srivastava and V.P. Singh, 1999. Serosurveillance of contagious
Caprine pleuropneumonia using enzyme linked immunosorbant assay. The Ind. J. of Anim. Scien., 69:9991001.

Singh, B and S. Prasad, 2010. Modelling of economic losses due to some important diseases in goats in India.. Agr. Eco.Re. Rev., 21: 297-304

Tariq, M.A. (1980). Studies on the incidence, epizootology and development of effective vaccines for the control of contagious Caprine pleuropneumonia, contagious agalactia in sheep and goats in Balochistan. Annual Report, Livestock Department, Government of Balochistan, Quetta, Pakistan

Teshale A.G. 2012. Seroprevalence and participatory study of contagious caprine plueropneumonia in Gulina wereda, Afar National Regional State, Ethiopia. Masters of veterinary science thesis.

\section{How to cite this article:}

Rishikesavan, R., K. M. Palanivel, S. Saravanan, P. Suresh and Sivaseelan, S. 2020. Epidemiological and economical study on Mycoplasmosis in goats in Tamil Nadu, India. Int.J.Curr.Microbiol.App.Sci. 9(01): 2268-2272. doi: https://doi.org/10.20546/ijcmas.2020.901.257 